\title{
QUEEN'S
UNIVERSITY
BELFAST
}

\section{Standardized Map of lodine Status in Europe}

Ittermann, T., Albrecht, D., Arohonka, P., Bílek, R., Dahl, L., Castro, J. J., Filipsson Nyström, H., Gaberšček, S., Garcia-Fuentes, E., Gheorghiu, M., Hubalewska-Dydejczyk, A., Hunziker, S., Jukic, T., Karanfilski, B., Koskinen, S., Kusic, Z., Majstorov, V., Makris, K., Markou, K., ... Völzke, H. (2020). Standardized Map of lodine Status in Europe. Thyroid : official journal of the American Thyroid Association. https://doi.org/10.1089/thy.2019.0353

\section{Published in:}

Thyroid : official journal of the American Thyroid Association

\section{Document Version:}

Peer reviewed version

\section{Queen's University Belfast - Research Portal:}

Link to publication record in Queen's University Belfast Research Portal

\section{Publisher rights}

Copyright 2020 Mary Ann Liebert. This work is made available online in accordance with the publisher's policies. Please refer to any applicable terms of use of the publisher.

\section{General rights}

Copyright for the publications made accessible via the Queen's University Belfast Research Portal is retained by the author(s) and / or other copyright owners and it is a condition of accessing these publications that users recognise and abide by the legal requirements associated with these rights.

\section{Take down policy}

The Research Portal is Queen's institutional repository that provides access to Queen's research output. Every effort has been made to ensure that content in the Research Portal does not infringe any person's rights, or applicable UK laws. If you discover content in the Research Portal that you believe breaches copyright or violates any law, please contact openaccess@qub.ac.uk. 


\section{QUEEN'S
UNIVERSITY
BELFAST}

\section{Standardized Map of lodine Status in Europe}

Ittermann, T., Albrecht, D., Arohonka, P., Bílek, R., Dahl, L., Castro, J. J., Filipsson Nyström, H., Gaberšček, S., Garcia-Fuentes, E., Gheorghiu, M., Hubalewska-Dydejczyk, A., Hunziker, S., Jukic, T., Karanfilski, B., Koskinen, S., Kusic, Z., Majstorov, V., Makris, K., Markou, K., ... Völzke, H. (2020). Standardized Map of lodine Status in Europe. Thyroid : official journal of the American Thyroid Association. https://doi.org/10.1089/thy.2019.0353

\section{Published in:}

Thyroid : official journal of the American Thyroid Association

\section{Document Version:}

Peer reviewed version

\section{Queen's University Belfast - Research Portal:}

Link to publication record in Queen's University Belfast Research Portal

\section{Publisher rights}

Copyright 2020 Mary Ann Liebert. This work is made available online in accordance with the publisher's policies. Please refer to any applicable terms of use of the publisher.

\section{General rights}

Copyright for the publications made accessible via the Queen's University Belfast Research Portal is retained by the author(s) and / or other copyright owners and it is a condition of accessing these publications that users recognise and abide by the legal requirements associated with these rights.

\section{Take down policy}

The Research Portal is Queen's institutional repository that provides access to Queen's research output. Every effort has been made to ensure that content in the Research Portal does not infringe any person's rights, or applicable UK laws. If you discover content in the Research Portal that you believe breaches copyright or violates any law, please contact openaccess@qub.ac.uk. 


\section{Standardized Map of lodine Status in Europe}

Till Ittermann ${ }^{1}$, Diana Albrecht ${ }^{1,31}$, Petra Arohonka ${ }^{2}$, 32, Radovan Bilek ${ }^{26}$, Joao J. de Castro $^{3}$, Lisbeth Dahl ${ }^{4}$, Helena Filipsson Nystrom ${ }^{5},{ }^{30}$, Simona Gaberscek ${ }^{6}$, Eduardo Garcia-Fuentes $^{18}$, Monica L Gheorghiu ${ }^{7}, 27$, Alicja Hubalewska-Dydejczyk ${ }^{8}$, Sandra Hunziker ${ }^{9}$, Tomislav Jukic ${ }^{10}$, Borislav Karanfilski ${ }^{11}$, Seppo Koskinen ${ }^{32}$, Zvonko Kusic $^{10}$, Venjamin Majstorov ${ }^{12}$, Konstantinos C Makris ${ }^{13}$, Kostas B Markou ${ }^{14}$, Christa Meisinger ${ }^{15,}{ }^{28}$, Neda Milevska Kostova ${ }^{11}$, Karen R Mullen ${ }^{29}$, Endre V. Nagy ${ }^{16}$, Valdis Pirags ${ }^{17}$, Gemma Rojo-Martinez ${ }^{18}$, Mira Samardzic ${ }^{19}$, Ljiljana Saranac ${ }^{20}$, leva Strele ${ }^{17}$, Michael Thamm ${ }^{21}$, Işık Top ${ }^{22}$, Malgorzata Trofimiuk-Müldner ${ }^{8}$, Belgin Ünal22, Seppo Koskinen ${ }^{32}$, Lluis Vila ${ }^{23}$, Paolo Vitti2 ${ }^{24}$, Benjamin Winter ${ }^{1}$, Jayne V. Woodside ${ }^{25}$, Katja Zaletel ${ }^{6}$, Vaclav Zamrazil| ${ }^{26 \dagger}$, Michael Zimmermann ${ }^{9}$, Iris Erlund ${ }^{2,32 \star}$, Henry Völzke ${ }^{1 *}$

${ }^{*}$ Contributed equally

tin memoriam

${ }^{1}$ Institute for Community Medicine, University Medicine Greifswald, Greifswald, Germany

${ }^{2}$ Department of Government Services, Finnish Institute for Health and Welfare, Helsinki, Finland

${ }^{3}$ Department of Endocrinology, Hospital das Forças Armadas, Lisbon, Portugal ${ }^{4}$ Food security and nutrition, Institute of Marine Research (IMR), Bergen, Norway Institute of Medicine, Sahlgrenska Academy, University of Gothenburg, Gothenburg, Sweden

${ }^{6}$ Department of Nuclear Medicine, University Medical Centre, Ljubljana, Slovenia ${ }^{7}$ Carol Davila University of Medicine and Pharmacy, Bucharest, Romania.

${ }^{8}$ Department of Endocrinology, Jagiellonian University Medical College, Krakow, Poland

${ }^{9} \mathrm{ETH}$, Department of Health Sciences and Technology, Zürich, Switzerland

10University of Zagreb, School of Medicine, Department of Oncology and Nuclear Medicine, University Hospital Centre Sestre Milosrdnice, Zagreb, Croatia

${ }^{11}$ Centre for Regional Policy Research and Cooperation "Studiorum", Skopje, North Macedonia

${ }^{12}$ Institute of Pathophysiology and Nuclear Medicine, Ss.Cyril and Methodius University, Skopje, Former Yougoslavian Rebublic of Macedonia 
${ }^{13}$ Cyprus International Institute for Environmental and Public Health, Cyprus University of Technology, Limassol, Cyprus

${ }^{14}$ Department of Endocrinology, Institute University of Patras Medical School, Patras, Greece

${ }^{15}$ Chair of Epidemiology, Ludwig-Maximilians Universität Munich, UNIKA-T Augsburg, Augsburg, Germany

${ }^{16}$ Division of Endocrinology, Faculty of Medicine, University of Debrecen, Debrecen, Hungary

${ }^{17}$ Department of Internal Medicine, University of Latvia, Riga, Latvia

${ }^{18}$ Department of Endocrinology and Nutrition, Hospital Regional Universitario de Málaga, IBIMA, Málaga, Spain

${ }^{19}$ Institute for Sick Children, Podgorica, Montenegro

${ }^{20}$ Department of Pediatrics, Faculty of Medicine, University of Niš, Niš, Serbia

${ }^{21}$ Department of Epidemiology and Health Monitoring, Robert Koch Institute, Berlin, Germany

${ }^{22}$ Dokuz Eylul University Medical Faculty, Department of Public Health, İzmir

${ }^{23}$ Department of Endocrinology and Nutrition, Hospital de Sant Joan Despi Moisès Broggi, Barcelona, Spain

${ }^{24}$ Department of Clinical and Experimental Medicine, University of Pisa, Pisa, Italy ${ }^{25}$ Centre for Public Health,Queen's University Belfast, Belfast, UK

${ }^{26}$ Institute of Endocrinology, Prague, Czech Republic

${ }^{27}$ C.I. Parhon National Institute of Endocrinology, Bucharest, Romania

${ }^{28}$ Independent Research Group Clinical Epidemiology, Helmholtz Zentrum München, German Research Center for Environmental Health, Neuherberg, Germany

${ }^{29}$ Belfast Health and Social Care Trust, Belfast, UK

30Department of Endocrinology, Sahlgrenska University Hospital, Göteborg, Sweden

${ }^{31}$ Leibniz Institute for Plasma Science and Technology (INP), Greifswald, Germany

32Department of Public Health Solutions, Finnish Institute for Health and Welfare, Helsinki, Finland 


\section{Address for correspondence:}

Till Ittermann, Dr. rer. med.

Institute for Community Medicine

Ernst Moritz Arndt University

\section{Walther Rathenau Str. 48}

D-17487 Greifswald; Germany

Phone: $\quad++49$ - $3834-867552$; FAX: $\quad++49-3834-866684$

e-mail: till.ittermann@uni-greifswald.de

\section{Short title: Standardized Map of lodine Status}

Keywords: iodine, iodine supply, epidemiology, method comparison

\section{E-mail addresses:}

diana.albrecht@inp-greifswald.de, petra.arohonka@thl.fi , rbilek@endo.cz, joao.castro@defesa.pt , Lisbeth.Dahl@hi.no, helena.filipsson@medic.gu.se , simona.gaberscek@kclj.si, edugf1@gmail.com, monicagheorghiu@yahoo.com , alahub@cm-uj.krakow.pl , sandra.hunziker@hest.ethz.ch ,tomislav.jukic@kbcsm.hr , karanfilski@hotmail.com ,seppo.koskinen@thl.fi, zvonko.kusic@zg.t-com.hr , venjamin.majstorov@gmail.com , konstantinos.makris@cut.ac.cy , markoukonst@upatras.gr, christa.meisinger@helmholtz-muenchen.de , nmilevska@studiorum.org.mk ,Karen.Mullan@belfasttrust.hscni.net , nagy@internal.med.unideb.hu, pirags@latnet.lv , gemma.rojo.exts@juntadeandalucia.es,samardzic@t-com.me , endoljilja@yahoo.com , ievastrele@inbox.lv, isikt0@gmail.com,ThammM@rki.de, mtrofimiuk@gmail.com, belgin.unal@deu.edu.tr, liisa.valsta@thl.fi, Lluis.Vila@sanitatintegral.org, paolo.vitti@med.unipi.it ,winterb@uni-greifswald.de , j.woodside@qub.ac.uk , katja.zaletel@kclj.si, vzamrazil@endo.cz , michael.zimmermann@hest.ethz.ch , iris.erlund@thl.fi , voelzke@uni-greifswald.de 


\section{Abstract}

\section{Background}

Knowledge about the population's iodine status is important, because it allows adjustment of iodine supply and prevention of iodine deficiency. The validity and comparability of iodine related population studies can be improved by standardization, which was one of the goals of the EUthyroid project. The aim of this study was to establish the first standardized map of iodine status in Europe by using standardized UIC data.

\section{Methods}

We established a gold-standard laboratory in Helsinki measuring UIC by inductively-coupled plasma-mass spectrometry. A total of 40 studies from 23 European countries provided 75 urine samples covering the whole range of concentrations. Conversion formulas for UIC derived from the gold-standard values were established by linear regression models and were used to post-harmonize the studies by standardizing the UIC data of the individual studies.

\section{Results}

In comparison to the EUthyroid gold-standard, mean UIC measurements were higher in 11 laboratories and lower in 10 laboratories. The mean differences ranged from $-36.6 \%$ to $49.5 \%$.

Of the 40 post-harmonized studies providing data for the standardization, 16 were conducted in schoolchildren, 13 in adults and 11 in pregnant women. Median standardized UIC was < $100 \mu \mathrm{g} / \mathrm{L}$ in 1 out of 16 (6.3\%) studies in schoolchildren, while in adults 7 out of $13(53.8 \%)$ studies had a median standardized UIC $<100 \mu \mathrm{g} / \mathrm{L}$. Seven out of $11(63.6 \%)$ studies in pregnant women revealed a median UIC $<150 \mu \mathrm{g} / \mathrm{L}$.

\section{Conclusions}

We demonstrated that iodine deficiency is still present in Europe, using standardized data from a large number of studies. Adults and pregnant women, particularly, are at risk for iodine deficiency, which calls for action. For instance, a more uniform European legislation on iodine fortification is warranted to ensure that non-iodized salt is replaced by iodized salt more often. In addition, further efforts should be put on harmonizing iodine related studies and iodine measurements to improve the validity and comparability of results. 
122 The iodine status of regions is assessed by median urinary iodine concentrations

123 (UIC) determined in representative samples of populations. National iodine

124 fortification programs are initiated and modified based on such studies. According to

125 the World Health Organization (WHO), a region is iodine sufficient if the median UIC

126 is $\geq 100 \mu \mathrm{g} / \mathrm{L}$ in non-pregnant populations (1). Based on this criterion, worldwide

127 maps of country-specific iodine status are drawn $(2,3)$. Laboratory methods for

128 measuring UIC, however, are heterogeneous hampering the comparability of iodine

129 monitoring studies (1). In a recent ring trial in Germany consisting of 300 samples,

130 variations of up to $50 \%$ were observed between different UIC laboratory methods.

131 These findings emphasize the need for standardization of iodine monitoring status as

132 well as UIC measurements ensuring valid estimates of the iodine status in

133 populations (4).

134 Besides the standardization of iodine monitoring studies, it will be necessary to

135 harmonize fortification programs. In Europe, iodine fortification programs differ

136 according to type of regulations (mandatory vs. voluntary iodine fortification), amount

137 of iodine used, and chemical form (iodine vs. iodate) $(5,6)$. The variety of iodine

138 fortification programs within Europe is a challenge for companies acting on the global

139 market. In consequence, large parts of Europe can be seen as mildly to moderately

140 iodine deficient with only $27 \%$ of European households having access to iodized salt

141 (7). Around 350 million citizens are exposed to iodine deficiency being at higher risk

142 for developing neurodevelopmental anomalies, since iodine deficiency remains as an

143 important yet preventable cause of brain damage (7). In contrast, the "Global

144 Scorecard of lodine Nutrition 2017" provided by the lodine Global Network (IGN)

145 shows that large parts of Europe are adequately supplied by iodine (2). This 
discrepancy may be explained by a lack of standardization of iodine measurements used for the IGN scorecard. Furthermore, iodine status is reported at the national level in the IGN map, but, particularly in countries with voluntary iodine supply, median iodine levels may differ substantially between subpopulations and regions within the respective country. Therefore, harmonized monitoring studies and UIC measurements as well as the consideration of regional and population differences, are of great importance when evaluating and monitoring the effectiveness of fortification programs. In our study, we aimed to standardize European iodine monitoring studies with respect to these considerations in order to establish a valid map of the iodine status in European populations.

\section{Material and Methods}

Within the framework of the EUthyroid consortium, we collected data on iodine status from 48 European studies using the EUthyroid data exchange system (8). Information on data owner, study design (population-based, volunteers or patients), study population (children, adults or pregnant women), year of data collection, blood sampling, urine collection, and laboratory methods were collected from each study.

Details of the included studies can be found in Supplementary Table 1. The maximum number of studies, for which UIC were analyzed in one laboratory, was three. The study region was assessed using the EU-recommended "Nomenclature of Territorial Units for Statistics" (NUTS) system, which classifies each European country by five hierarchical levels (9). For each study participating in the cross-lab comparison, the relevant ethics approval was obtained and each study followed the declaration of Helsinki.

The individual studies were post-harmonized by standardizing the UIC data. For this purpose, we established a gold-standard EUthyroid laboratory at THL in Helsinki, 
171 where UIC was measured with inductively coupled plasma - mass spectrometry (ICP-MS) using an Agilent 7800 ICP-MS system (Agilent Technologies Inc., Santa Clara, CA, USA). One-hundred $\mu$ l of urine was extracted using ammonium hydroxide solution. lodine was scanned on $\mathrm{m} / \mathrm{z}=127$ and tellurium was used as internal standard. The National Institute of Standards and Technology (NIST) reference standard materials SRM2670a (with certified mass concentration value) and SRM3668 Level 1 and Level 2 were used to ensure accuracy of urinary iodine determinations. Coefficient of variation (CV) of control samples was $2.9 \% \pm 0.8$ during the course of the study. The laboratory participates regularly successfully in the external quality assessment scheme "Ensuring the Quality of Urinary lodine Procedures" (EQUIP) organized by the Centers for Disease Control and Prevention.

For standardization of the UIC data from the individual studies, each partner was asked to send 75 spot urine samples to the EUthyroid gold standard laboratory. This selected the following way: UIC measurements. Since the distribution of UIC varies according to current iodine supply of the respective study region, it is not useful to determine one strict cut-off to define these marginal areas. Instead the cut-offs should be determined study-specific based on distributional characteristics. To detect deviations at either end of the UIC distribution, the low and the high end were oversampled. Thus, samples were

- Between $0-5^{\text {th }}$ percentile -12 samples

- Between $5^{\text {th }}$ percentile $-25^{\text {th }}$ percentile -13 samples

- Between $25^{\text {th }}$ percentile $-50^{\text {th }}$ percentile -13 samples

- Between $50^{\text {th }}$ percentile $-75^{\text {th }}$ percentile -13 samples

- Between $75^{\text {th }}$ percentile $-95^{\text {th }}$ percentile -13 samples 
- Between $95^{\text {th }}$ percentile $-100^{\text {th }}$ percentile -11 samples

Based on the comparisons, we calculated mean deviations \pm 1.96 standard deviations in \% by Bland \& Altman plots. Correlations between two laboratory methods were assessed by linear regression (10). Conversions formulas derived from linear regression models were established and applied to the original studies. We also re-calculated formulas using Passing-Bablok regression for all laboratories and found no substantial differences to our findings when applying these formulas to the study data (data not shown).

Out of the 48 studies, eight studies were not able to submit samples to the EUthyroid laboratory resulting in a total number of 40 standardized studies from 23 European countries. Standardized UIC were calculated as median for each of the studies and plotted on the European map. Data analyses were conducted using Stata 15.1 (Stata Corporation, College Station, TX, USA). Maps were generated in ArcGIS (Environmental Systems Research Institute (ESRI), ArcGIS Release 10.3.1, Redlands, CA, USA).

\section{Results}

In comparison to the gold-standard EUthyroid laboratory, UIC measurements were on average higher in 11 laboratories and lower in 10 laboratories (Table 1). The mean differences ranged from $-36.6 \%$ to $49.5 \%$. Correlations of UIC to the goldstandard EUthyroid laboratory were $\geq 0.9$ for 9 laboratories (42.9\%), $0.8-0.9$ for 5 laboratories (23.8\%), $0.7-0.8$ for 3 laboratories (14.3\%), and $<0.7$ for 4 laboratories (19.0\%). Conversion formulas used for generating standardized UIC values are given in Table 1. 
219 Of the 40 standardized studies from 23 countries, $16(40.0 \%)$ were conducted in 220 schoolchildren, $13(32.5 \%)$ in adults and $11(27.5 \%)$ in pregnant women. Table 2 221 shows the median standardized UIC for all 40 studies and in Figure 1 the median

222 standardized UIC are printed on the European map. Studies are presented

223 depending on the exact study region (status is not extrapolated to the national level)

224 and very small study regions are highlighted by circles for better visibility. In population monitoring of iodine status using UIC, schoolchildren have been least impacted by thyroid medication (11), therefore preference has been given to studies carried out in schoolchildren. Thus, the UIC data have been selected for each country in the following order of priority: data from the most recent nationally representative survey carried out in (i) schoolchildren, (ii) adults, (iii) pregnant women. In the absence of recent national surveys, subnational data were used in the same order of priority.

European maps of standardized UIC in school children, adults and pregnant women are displayed in Figures $2-4$ on the country level. Median standardized UIC was < $100 \mu \mathrm{g} / \mathrm{L}$ in 1 out 16 (6.3\%) studies in schoolchildren, while in adults 7 out 13 (53.8\%) studies had a median standardized UIC $<100 \mu \mathrm{g} / \mathrm{L}$. In tendency, countries from Eastern Europe were better supplied by iodine than Northern and Western European countries. Seven out of eleven (63.6\%) studies in pregnant women revealed a median standardized UIC $<150 \mu \mathrm{g} / \mathrm{L}$. In some countries median UIC differed strongly across subpopulations. Especially in Latvia, but also in Germany, Switzerland, Spain,

Czech Republic, and Macedonia schoolchildren had higher median UIC than adults.

\section{Discussion}

We observed substantial differences in UIC measurements between different laboratories. These results show that standardizing UIC measurements is important 
when comparing results. Looking for example at the population-based German adults studies DEGS (nationwide, 2011), SHIP-Trend (North-East Germany, 2012), and KORA (South Germany, 2008), the range of non- standardized median UIC varied substantially and were between $44 \mu \mathrm{g} / \mathrm{L}$ and $158 \mu \mathrm{g} / \mathrm{L}$. Even though voluntary iodine fortification in Germany can lead to regional differences in iodine status, such large differences were not expected and do not seem plausible. However, different laboratories were responsible for the UIC measurements in the latter studies and we previously demonstrated larger differences in UIC measurements across these laboratories (4). While UIC measurements by Sandell-Kolthoff reaction were quite comparable to UIC measurements by the gold-standard ICP-MS for one laboratory, there were substantial differences in UIC for the other two laboratories using SandellKolthoff reaction compared to the ICP-MS method (4). Thus, we believe that a potential explanation for the differences across the laboratories is the use of different digestion methods (4). Particularly, a not sufficient amount of the oxidizing digestion acid may result in elevated UIC measurements. After standardizing data from the European studies using the gold-standard EUthyroid laboratory, the median UIC were less variable, ranging between $51 \mu \mathrm{g} / \mathrm{L}$ and $93 \mu \mathrm{g} / \mathrm{L}$, which indicates that Germany is currently mild to moderately iodine deficient.

Our standardized UIC data shows that mild-to-moderate iodine deficiency is still common in the adult population and in pregnant women in Europe, according to WHO criteria (1). Schoolchildren, on the other hand, are mostly iodine-sufficient, according to this study. Compared to children and adolescents, adults are likely to obtain less iodine from the diet because of lower consumption of milk products, the main source of dietary iodine in many countries (12-14). This, together with larger urine volumes in adults compared to schoolchildren (15) or amount of liquids 
consumed, may explain the higher frequency of adult studies with median $\mathrm{UIC}<100$ $\mu \mathrm{g} / \mathrm{L}$ compared to studies in schoolchildren.

Pregnant women represent a specific subgroup of the general population. During pregnancy, iodine demand is higher and iodine clearance in the kidney increases, which is taken into account in the WHO pregnancy population cut-off for sufficient iodine supply $(150 \mu \mathrm{g} / \mathrm{L})$ in UIC (1). Pregnant women are recommended to take iodine supplementation in some countries (16), which hampers the comparison between iodine status in pregnant women and other populations in a study region. Furthermore, physiological changes during pregnancy and the fact that sample collection from pregnant women is sometimes performed in conjunction with ultrasound measurements, when they are advised to drink more water, leads to a higher dilution of the urine samples and in consequence to lower UIC (17). For these reasons, monitoring studies in pregnant women should not be used to characterize the iodine status of the general population and should be assessed separately from monitoring studies in children and adults. Our data demonstrates that pregnant women are particularly affected by iodine deficiency in Europe, emphasizing the importance of monitoring studies and an improved iodine status in this vulnerable subgroup.

Our standardized UIC data shows iodine deficiency in $53.8 \%$ of all adult studies, but iodine deficiency in only $6.3 \%$ of studies in schoolchildren. The 2017 iodine scorecard of the IGN indicates only two European countries as iodine deficient, but in the IGN scorecard, the iodine status of all countries with data is based on studies in schoolchildren, with the exception of Finland (2). WHO recommends monitoring of UIC in school-age children as a proxy for the general population (1). Although WHO also defines adequate iodine intake in adults as a median UIC value $\geq 100 \mu \mathrm{g} / \mathrm{L}$ (1), 
the scientific basis for this threshold is weak (18). Future research to define a functional UIC cut-off value for adults indicating iodine deficiency would be valuable.

For the IGN scorecard, studies were not standardized, which may also be an explanation for the differences to our map. Another potential source of variation when comparing iodine surveys is the use of iodine-creatinine ratios (ICR). ICR has the advantage that UIC measurements are standardized to dilution of the urine samples, but the measurement error of ICR is larger than for UIC, because two biomarkers are set into context. In large populations the effect of the dilution of urine samples should cancel out. In a recent study it was reported that a study size of 500 individuals is needed to determine the iodine level of a population with a precision of $5 \%$ (19). Thus, we recommend to analyze UIC instead of the ICR in larger population studies. In pregnant women, however, ICR data is useful, because of the large variation in the dilution of urine during pregnancy.

lodine supply appears to be better in Eastern European countries compared to Western or Northern European countries. This may be due to the fact, that in Eastern Europe iodine fortification programs are obligatory and well monitored, whereas in the rest of Europe iodine fortification programs are mostly voluntary (6).

The major strength of our study is that we, for the first time, present standardized data on iodine status for Europe. For standardization of each laboratory we used a sufficient number of samples $(n=75)$ covering the whole range of UIC Our standardization approach was not ideal, because it was based on post-harmonization of data from existing studies. However, it yields a general view of the current iodine status across Europe, and indicates that pre-harmonized studies are needed, as well as actions to improve iodine intake in certain population groups. The main limitations imitations of our study arise from differences of the monitoring studies included, for 
example in recruitment procedures (population-based or not), size of study (ranging from 74 to 14,641 study participants) or timing of sample collection. Furthermore, subnational UIC surveys should be interpreted with caution. These surveys are commonly carried out to provide a rapid assessment of population iodine status, but due to a lack of sampling rigor, they may over- or underestimate the iodine status at the national level. Even though schoolchildren are the ideal population, they are not representative for adult populations, because adolescents and adults are expected to have a lower UIC due to differences in diet. Particularly, the consumption of milk varies significantly between these subpopulations.

In the EUthyroid project we standardized the data from European iodine monitoring studies and demonstrated that iodine status is generally adequate in schoolchildren but iodine deficiency may still present in adults and pregnant women. An improvement of the iodine supply in Europe is hampered by different national legislations leading to a disproportionate use of iodized salt in processed food production (6). Therefore, a more uniform European legislation on iodine fortification is required. The standardized European map of UIC is an important milestone to provide the robust evidence to encourage stakeholders to improve and harmonize legislations towards Europe and beyond. In future studies, much more effort should be put on harmonizing the procedures used in iodine monitoring studies, beginning from the planning phase and including sample collection procedures and UIC measurements, to improve the validity and comparability of iodine studies.

\section{Funding}

The EUthyroid project has received funding from the European Union's Horizon 2020 research and innovation program under grant agreement number 634453. 
343 Disclosure Statement

344 No competing financial interests exist 


\section{Literature}

1. World Health Organization 2007 Assessment of lodine Deficiency Disorders and Monitoring their Elimination. A Guide for Programme Managers (Third edition).

2. Iodine Global Network. Global map of iodine nutrition (http://www.ign.org/scorecard.htm). (Last accessed on 2018/09/12, 2018).

3. Zimmermann MB, Andersson M 2012 Update on iodine status worldwide. Curr Opin Endocrinol Diabetes Obes 19:382-387.

4. Ittermann T, Johner S, Below H, Leiterer M, Thamm M, Remer T, Volzke H 2017 Interlaboratory variability of urinary iodine measurements. Clin Chem Lab Med.

5. Nystrom HF, Brantsaeter AL, Erlund I, Gunnarsdottir I, Hulthen L, Laurberg P, Mattisson I, Rasmussen LB, Virtanen S, Meltzer HM 2016 lodine status in the Nordic countries - past and present. Food Nutr Res 60:31969.

6. Volzke H, Caron P, Dahl L, de Castro JJ, Erlund I, Gaberscek S, Gunnarsdottir I, HubalewskaDydejczyk A, Ittermann T, Ivanova L, Karanfilski B, Khattak RM, Kusic Z, Laurberg P, Lazarus JH, Markou KB, Moreno-Reyes R, Nagy EV, Peeters RP, Pirags V, Podoba J, Rayman MP, Rochau U, Siebert U, Smyth PP, Thuesen BH, Troen A, Vila L, Vitti P, Zamrazil V, Zimmermann MB 2016 Ensuring Effective Prevention of lodine Deficiency Disorders. Thyroid 26:189-196.

7. Lazarus JH 2014 lodine status in europe in 2014. Eur Thyroid J 3:3-6.

8. The EUthyroid Consortium. EUthyroid Data Exchange System (https://dex.euthyroid.medizin.uni-greifswald.de/dex/). (Last accessed on 2018-09-12, 2018).

9. Eurostat. 2007 Regions in the European Union. Nomenclature of territorial units for statistics - NUTS 2006/EU-27. Office for Official Publications of the European Communities, Luxembourg.

10. Cashman KD, Dowling KG, Skrabakova Z, Kiely M, Lamberg-Allardt C, Durazo-Arvizu RA, Sempos CT, Koskinen S, Lundqvist A, Sundvall J, Linneberg A, Thuesen B, Husemoen LL, Meyer HE, Holvik K, Gronborg IM, Tetens I, Andersen R 2015 Standardizing serum 25hydroxyvitamin D data from four Nordic population samples using the Vitamin $D$ Standardization Program protocols: Shedding new light on vitamin D status in Nordic individuals. Scand J Clin Lab Invest 75:549-561.

11. Diaz A, Lipman Diaz EG 2014 Hypothyroidism. Pediatr Rev 35:336-347; quiz 348-339.

12. Rasmussen LB, Ovesen L, Bulow I, Jorgensen T, Knudsen N, Laurberg P, Pertild H 2002 Dietary iodine intake and urinary iodine excretion in a Danish population: effect of geography, supplements and food choice. Br J Nutr 87:61-69.

13. Thamm M, Ellert U, Thierfelder W, Liesenkotter KP, Volzke H 2007 [lodine intake in Germany. Results of iodine monitoring in the German Health Interview and Examination Survey for Children and Adolescents (KiGGS)]. Bundesgesundheitsblatt Gesundheitsforschung Gesundheitsschutz 50:744-749.

14. Dahl L, Opsahl JA, Meltzer HM, Julshamn K 2003 lodine concentration in Norwegian milk and dairy products. Br J Nutr 90:679-685.

15. Johner SA, Shi L, Remer T 2010 Higher urine volume results in additional renal iodine loss. Thyroid 20:1391-1397.

16. Ittermann T, Volzke H, Krey A, Remer T, Heckmann M, Lange A, Kramer A, Below H 2018 Median urinary iodine concentration reflected sufficient iodine supply in neonates from Northeast Germany in 2005-2006. Eur J Nutr.

17. Bath SC, Rayman MP 2015 A review of the iodine status of UK pregnant women and its implications for the offspring. Environ Geochem Health 37:619-629.

18. Zimmermann MB, Andersson M 2012 Assessment of iodine nutrition in populations: past, present, and future. Nutr Rev 70:553-570. 
19. Andersen S, Karmisholt J, Pedersen KM, Laurberg P 2008 Reliability of studies of iodine intake and recommendations for number of samples in groups and in individuals. Br J Nutr 99:813818.

396 


\section{Supplementary Table 1. Description of the involved studies}

\begin{tabular}{|c|c|c|c|c|}
\hline Country & Year & Study population & lodine measurement & Reference \\
\hline Croatia & $2014-2016$ & $\begin{array}{l}\text { Simplify study - population-based sample } \\
\text { of } 200 \text { children, } 227 \text { adults and } 202 \\
\text { pregnant women }\end{array}$ & $\begin{array}{l}\text { Sandell-Kolthoff reaction } \\
\text { (Wawschinek modification) }\end{array}$ & $(1)$ \\
\hline Cyprus & 2014 & $\begin{array}{l}\text { Sample of } 121 \text { adults recruited from } \\
\text { hospitals and advertisements }\end{array}$ & ICP-MS & \\
\hline Czech Republic & 2006 & $\begin{array}{l}\text { Study in Zdar nad Sazavou - population- } \\
\text { based sample of } 302 \text { children and } 288 \\
\text { adults }\end{array}$ & $\begin{array}{l}\text { Sandell-Kolthoff reaction } \\
\text { subsequent to dry alkaline }\end{array}$ & $(2)$ \\
\hline Finland & 2017 & $\begin{array}{l}\text { FinHealth } 2017 \text { Study - Nationally } \\
\text { representative survey, subsample with } \\
1542 \text { adults (Findiet } 2017 \text { Survey) }\end{array}$ & ICP-MS & \\
\hline Germany & $2003-2006$ & $\begin{array}{l}\text { KiGGS study - nationwide population- } \\
\text { based study in } 14,641 \text { children and } \\
\text { adolescents }\end{array}$ & $\begin{array}{l}\text { Sandell-Kolthoff reaction with } \\
\text { ammonium persulfate digestion }\end{array}$ & (3) \\
\hline Germany & $2008-2012$ & $\begin{array}{l}\text { SHIP-Trend - population-based study in } \\
4287 \text { adults }\end{array}$ & $\begin{array}{l}\text { Sandell-Kolthoff reaction } \\
\text { (Wawschinek modification) }\end{array}$ & (4) \\
\hline Germany & $2008-2011$ & $\begin{array}{l}\text { DEGS - nation-wide population-based } \\
\text { study in } 7022 \text { adults }\end{array}$ & $\begin{array}{l}\text { Sandell-Kolthoff reaction with } \\
\text { ammonium persulfate digestion }\end{array}$ & (5) \\
\hline Germany & $2006-2008$ & $\begin{array}{l}\text { KORA-F4 - Population-based study in } \\
2999 \text { adults }\end{array}$ & $\begin{array}{l}\text { Sandell-Kolthoff reaction } \\
\text { (Wawschinek modification) }\end{array}$ & (6) \\
\hline Germany & $1997-2001$ & SHIP-0 - population-based study in 4260 & Sandell-Kolthoff reaction & $(7)$ \\
\hline
\end{tabular}




\begin{tabular}{|c|c|c|c|c|}
\hline Country & Year & Study population & lodine measurement & Reference \\
\hline & & adults & (Wawschinek modification) & \\
\hline Greece & $2012-2015$ & $\begin{array}{l}\text { Representative sample of } 1135 \text { pregnant } \\
\text { women }\end{array}$ & $\begin{array}{l}\text { Sandell-Kolthoff reaction with } \\
\text { ammonium persulfate digestion }\end{array}$ & (8) \\
\hline Hungary & 2018 & $\begin{array}{l}\text { One randomly-selected school including } \\
110 \text { children }\end{array}$ & $\begin{array}{l}\text { Sandell-Kolthoff method adopted } \\
\text { to microplate }\end{array}$ & \\
\hline Hungary & 2016 & $\begin{array}{l}\text { GS16 - } 190 \text { randomly selected pregnant } \\
\text { women in week } 16 \text { of pregnancy }\end{array}$ & $\begin{array}{l}\text { Sandell-Kolthoff method adopted } \\
\text { to microplate }\end{array}$ & \\
\hline $\begin{array}{l}\text { Northern Ireland } \\
\text { and Republic of } \\
\text { Ireland }\end{array}$ & $2014-2015$ & 901 schoolgirls aged $14-15$ years & $\begin{array}{l}\text { Sandell-Kolthoff reaction with } \\
\text { multiplate persulphate digestion }\end{array}$ & (9) \\
\hline $\begin{array}{l}\text { Northern Ireland } \\
\text { (UK) }\end{array}$ & $2014-2015$ & $\begin{array}{l}240 \text { pregnant women recruited from } \\
\text { maternity hospital }\end{array}$ & $\begin{array}{l}\text { Sandell-Kolthoff reaction with } \\
\text { multiplate persulphate digestion }\end{array}$ & $(10)$ \\
\hline Italy & 2016 & 100 school children from Tuscany & ICP-MS & \\
\hline Latvia & $2010-2011$ & $\begin{array}{l}\text { Study of } 915 \text { school children from } 46 \\
\text { randomly-selected schools }\end{array}$ & $\begin{array}{l}\text { Sandell-Kolthoff reaction with } \\
\text { ammonium persulfate digestion }\end{array}$ & $(11)$ \\
\hline Latvia & $2013-2014$ & $\begin{array}{l}\text { Study of } 743 \text { pregnant women recruited by } \\
\text { gynecologists from all regions }\end{array}$ & $\begin{array}{l}\text { Sandell-Kolthoff reaction with } \\
\text { ammonium persulfate digestion }\end{array}$ & (12) \\
\hline North Macedonia & 2016 & $\begin{array}{l}\text { Population-based sample of } 1167 \text { school } \\
\text { children aged } 8-10 \text { years }\end{array}$ & $\begin{array}{l}\text { Sandell-Kolthoff reaction with } \\
\text { ammonium persulfate digestion }\end{array}$ & \\
\hline North Macedonia & 2017 & $\begin{array}{l}\text { Sample of } 593 \text { pregnant women recruited } \\
\text { by advertisement }\end{array}$ & ICP-MS & \\
\hline Montenegro & 2016 & $\begin{array}{l}\text { Population-based sample of } 406 \text { school } \\
\text { children }\end{array}$ & $\begin{array}{l}\text { Sandell-Kolthoff reaction with } \\
\text { ammonium persulfate digestion }\end{array}$ & \\
\hline
\end{tabular}




\begin{tabular}{|c|c|c|c|c|}
\hline Country & Year & Study population & lodine measurement & Reference \\
\hline Norway & 2015 & $\begin{array}{l}\text { FINS-TEENS -Randomized study of } 457 \\
\text { adolescents aged } 14-15 \text { years from } 8 \\
\text { secondary schools }\end{array}$ & ICP-MS & (13) \\
\hline Poland & 2017 & $\begin{array}{l}\text { Survey on iodine nutrition within the the } \\
\text { National Health Programme including } \\
1000 \text { schoolchildren and } 300 \text { pregnant } \\
\text { recruited on a voluntary basis }\end{array}$ & Sandell-Kolthoff reaction & \\
\hline Portugal & $2010-2011$ & $\begin{array}{l}\text { Sample of } 4390 \text { school children and } 4107 \\
\text { pregnant women recruited voluntarily }\end{array}$ & Colorimetric method & \\
\hline Romania & $2015-2016$ & $\begin{array}{l}\text { Sample of } 317 \text { pregnant women recruited } \\
\text { from ambulatory care }\end{array}$ & $\begin{array}{l}\text { Sandell-Kolthoff reaction with } \\
\text { ammonium persulfate digestion }\end{array}$ & \\
\hline Serbia & 2018 & $\begin{array}{l}74 \text { children with thyroid disease recruited } \\
\text { from ambulatory care }\end{array}$ & $\begin{array}{l}\text { Chemiluminescent microparticule } \\
\text { immunoassay }\end{array}$ & \\
\hline Slovenia & 2017 & Sample of 292 women of reproductive age & $\begin{array}{l}\text { Sandell-Kolthoff reaction with } \\
\text { ammonium persulfate digestion } \\
\text { adopted to microplate }\end{array}$ & \\
\hline Spain & $2010-2011$ & $\begin{array}{l}\text { Tirokid study - Population-based sample } \\
\text { of } 1750 \text { children }\end{array}$ & $\begin{array}{l}\text { Sandell-Kolthoff reaction (Benotti } \\
\text { \& Benotti modification) with chloric } \\
\text { acid digestion }\end{array}$ & (14) \\
\hline Spain & $2008-2010$ & $\begin{array}{l}\text { Di@bet.es - Population-based study in } \\
4383 \text { adults }\end{array}$ & $\begin{array}{l}\text { Sandell-Kolthoff reaction (Benotti } \\
\text { \& Benotti modification) with chloric } \\
\text { acid digestion }\end{array}$ & (15) \\
\hline
\end{tabular}




\begin{tabular}{|c|c|c|c|c|}
\hline Country & Year & Study population & lodine measurement & Reference \\
\hline Sweden & $2006-2007$ & $\begin{array}{l}\text { National sample of } 866 \text { school-aged } \\
\text { children }\end{array}$ & $\begin{array}{l}\text { Sandell-Kolthoff reaction (Pino } \\
\text { modification) }\end{array}$ & (16) \\
\hline Sweden & $1987-2001$ & $\begin{array}{l}\text { Swedish Obese Subjects (SOS) Study - } \\
565 \text { obese subjects choosing bariatric } \\
\text { surgery }\end{array}$ & $\begin{array}{l}\text { Sandell-Kolthoff reaction (Pino } \\
\text { modification) }\end{array}$ & $(17)$ \\
\hline Sweden & $2006-2011$ & $\begin{array}{l}\text { Karlstad-Uppsala-Study - Population- } \\
\text { based study in } 459 \text { pregnant women }\end{array}$ & $\begin{array}{l}\text { Sandell-Kolthoff reaction (Pino } \\
\text { modification) }\end{array}$ & (18) \\
\hline Switzerland & $2015-2016$ & $\begin{array}{l}\text { National representative study in } 727 \\
\text { school children, } 345 \text { women of } \\
\text { reproductive age and } 358 \text { pregnant } \\
\text { women }\end{array}$ & $\begin{array}{l}\text { Sandell-Kolthoff reaction (Pino } \\
\text { modification) }\end{array}$ & (19) \\
\hline Turkey & $2016-2017$ & $\begin{array}{l}\text { Sample of } 165 \text { high school and vocational } \\
\text { school students aged } 15-22\end{array}$ & $\begin{array}{l}\text { Sandell-Kolthoff reaction with } \\
\text { ammonium persulfate digestion }\end{array}$ & \\
\hline
\end{tabular}




\section{References}

1. Dold S, Zimmermann MB, Jukic T, Kusic Z, Jia Q, Sang Z, Quirino A, San Luis TOL, Fingerhut R, Kupka R, Timmer A, Garrett GS, Andersson M 2018 Universal Salt lodization Provides Sufficient Dietary lodine to Achieve Adequate lodine Nutrition during the First 1000 Days: A Cross-Sectional Multicenter Study. J Nutr 148:587-598.

2. Bilek R, Bednar J, Zamrazil V 2005 Spectrophotometric determination of urinary iodine by the Sandell-Kolthoff reaction subsequent to dry alkaline ashing. Results from the Czech Republic in the period 1994-2002. Clin Chem Lab Med 43:573-580.

3. Thamm M, Ellert U, Thierfelder W, Liesenkotter KP, Volzke H 2007 [lodine intake in Germany. Results of iodine monitoring in the German Health Interview and Examination Survey for Children and Adolescents (KiGGS)]. Bundesgesundheitsblatt Gesundheitsforschung Gesundheitsschutz 50:744749.

4. Khattak RM, Ittermann T, Nauck M, Below H, Volzke H 2016 Monitoring the prevalence of thyroid disorders in the adult population of Northeast Germany. Popul Health Metr 14:39.

5. Scheidt-Nave C, Kamtsiuris P, Gosswald A, Holling H, Lange M, Busch MA, Dahm S, Dolle R, Ellert U, Fuchs J, Hapke U, Heidemann C, Knopf H, Laussmann D, Mensink GB, Neuhauser H, Richter A, Sass AC, Rosario AS, Stolzenberg H, Thamm M, Kurth BM 2012 German health interview and examination survey for adults (DEGS) - design, objectives and implementation of the first data collection wave. BMC Public Health 12:730.

6. Meisinger C, Ittermann T, Wallaschofski H, Heier M, Below H, Kramer A, Doring A, Nauck M, Volzke H 2012 Geographic variations in the frequency of thyroid disorders and thyroid peroxidase antibodies in persons without former thyroid disease within Germany. Eur J Endocrinol 167:363-371.

7. Volzke H, Ludemann J, Robinson DM, Spieker KW, Schwahn C, Kramer A, John U, Meng W 2003 The prevalence of undiagnosed thyroid disorders in a previously iodine-deficient area. Thyroid 13:803-810.

8. Koukkou EG, Ilias I, Mamalis I, Markou KB 2017 Pregnant Greek Women May Have a Higher Prevalence of lodine Deficiency than the General Greek Population. Eur Thyroid J 6:26-30.

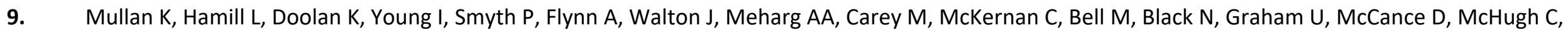
McMullan P, McQuaid S, O'Loughlin A, Tuthill A, Bath SC, Rayman M, Woodside JV 2019 lodine status of teenage girls on the island of Ireland. Eur J Nutr.

10. McMullan P, Hamill L, Doolan K, Hunter A, McCance D, Patterson C, Smyth P, Woodside JV, Mullan K 2019 lodine deficiency among pregnant women living in Northern Ireland. Clin Endocrinol (Oxf).

11. Konrade I, Neimane L, Makrecka M, Strele I, Liepinsh E, Lejnieks A, Vevere P, Gruntmanis U, Pirags V, Dambrova M 2014 A cross-sectional survey of urinary iodine status in Latvia. Medicina (Kaunas) 50:124-129.

12. Konrade I, Kalere I, Strele I, Makrecka-Kuka M, Jekabsone A, Tetere E, Veisa V, Gavars D, Rezeberga D, Pirags V, Lejnieks A, Dambrova M 2015 lodine deficiency during pregnancy: a national cross-sectional survey in Latvia. Public Health Nutr 18:2990-2997.

13. Skotheim S, Dahl L, Handeland K, Froyland L, Lie O, Oyen J, Kjellevold M, Stormark KM, Graff IE 2017 Design of the FINS-TEENS study: A randomized controlled trial assessing the impact of fatty fish on cognitive performance in adolescents. Scand J Public Health 45:621-629. 
14. Vila L, Donnay S, Arena J, Arrizabalaga JJ, Pineda J, Garcia-Fuentes E, Garcia-Rey C, Marin JL, Serra-Prat M, Velasco I, Lopez-Guzman A, Luengo LM, Villar A, Munoz Z, Bandres O, Guerrero E, Munoz JA, Moll G, Vich F, Menendez E, Riestra M, Torres Y, Beato-Vibora P, Aguirre M, Santiago P, Aranda J, Gutierrez-Repiso C 2016 lodine status and thyroid function among Spanish schoolchildren aged 6-7 years: the Tirokid study. Br J Nutr 115:1623-1631.

15. Soriguer F, Garcia-Fuentes E, Gutierrez-Repiso C, Rojo-Martinez G, Velasco I, Goday A, Bosch-Comas A, Bordiu E, Calle A, Carmena R, Casamitjana R, Castano L, Castell C, Catala M, Delgado E, Franch J, Gaztambide S, Girbes J, Gomis R, Gutierrez G, Lopez-Alba A, Martinez-Larrad MT, Menendez E, Mora-Peces I, Ortega E, Pascual-Manich G, Serrano-Rios M, Valdes S, Vazquez JA, Vendrell J 2012 lodine intake in the adult population. Di@bet.es study. Clin Nutr 31:882-888.

16. Andersson M, Berg G, Eggertsen R, Filipsson H, Gramatkovski E, Hansson M, Hulthen L, Milakovic M, Nystrom E 2009 Adequate iodine nutrition in Sweden: a cross-sectional national study of urinary iodine concentration in school-age children. Eur I Clin Nutr 63:828-834.

17. Manousou S, Carlsson LMS, Eggertsen R, Hulthen L, Jacobson P, Landin-Wilhelmsen K, Trimpou P, Svensson PA, Nystrom HF 2018 lodine Status After Bariatric Surgery-a Prospective 10-Year Report from the Swedish Obese Subjects (SOS) Study. Obes Surg 28:349-357.

18. Granfors M, Andersson M, Stinca S, Akerud H, Skalkidou A, Poromaa IS, Wikstrom AK, Nystrom HF 2015 lodine deficiency in a study population of pregnant women in Sweden. Acta Obstet Gynecol Scand 94:1168-1174.

19. Andersson M, Hunziker S, Fingerhut R, Zimmermann MB, Herter-Aeberli I 2019 Effectiveness of increased salt iodine concentration on iodine status: trend analysis of cross-sectional national studies in Switzerland. Eur J Nutr. 
Table 1. Laboratory comparisons to the EUthyroid central lab for urinary iodine concentrations (UIC)

\begin{tabular}{|c|c|c|c|c|c|}
\hline Laboratory & $\begin{array}{c}\text { Difference in } \\
\text { UIC; \% Mean } \\
\left(1.96^{\star} \text { SD }\right)\end{array}$ & Correlation & $\mathbf{p}_{\text {int }}$ & $\mathbf{p}_{\text {slope }}$ & $\begin{array}{c}\text { Conversion } \\
\text { formula }\end{array}$ \\
\hline 1 & $-0.1(14.7)$ & 0.99 & 0.925 & 0.356 & $-0.23+1.01^{*} \mathrm{UIC}$ \\
\hline 2 & $-18.2(53.2)$ & 0.98 & 0.667 & $<0.001$ & $-0.90+1.16^{*} \mathrm{UIC}$ \\
\hline 3 & $-15.5(75.8)$ & 0.98 & 0.022 & 0.458 & $17.44+0.98^{\star} \mathrm{UIC}$ \\
\hline 4 & $13.0(27.0)$ & 0.97 & $<0.001$ & 0.040 & $-29.2+1.04^{*} \mathrm{UIC}$ \\
\hline 5 & $-2.6(49.7)$ & 0.95 & 0.836 & 0.225 & $-1.05+1.04^{*} \mathrm{UIC}$ \\
\hline 6 & 32.3 (32.9) & 0.95 & 0.074 & $<0.001$ & $15.71+0.66^{*} \mathrm{UIC}$ \\
\hline 7 & $3.4(37.2)$ & 0.95 & 0.892 & 0.179 & $0.91+0.97^{*} \mathrm{UIC}$ \\
\hline 8 & $5.5(79.2)$ & 0.93 & 0.287 & 0.972 & $-5.65+1.00 * \mathrm{UIC}$ \\
\hline 9 & $14.5(27.3)$ & 0.92 & 0.693 & $<0.001$ & $2.39+0.86 * \mathrm{UIC}$ \\
\hline 10 & $12.4(44.4)$ & 0.89 & 0.363 & $<0.001$ & $5.02+0.83^{*} \mathrm{UIC}$ \\
\hline 11 & $-15.9(143.9)$ & 0.87 & 0.337 & 0.124 & $9.48+0.93^{*} \mathrm{UIC}$ \\
\hline 12 & 34.7 (89.9) & 0.83 & $<0.001$ & $<0.001$ & $-67.37+1.54^{*} \mathrm{UIC}$ \\
\hline 13 & $49.5(63.1)$ & 0.82 & 0.163 & $<0.001$ & $-6.61+0.63^{*} \mathrm{UIC}$ \\
\hline 14 & $30.0(51.1)$ & 0.82 & 0.096 & 0.161 & $-27.27+0.93^{*} \mathrm{UIC}$ \\
\hline 15 & $10.9(83.2)$ & 0.77 & 0.824 & 0.723 & $-6.39+0.98^{*} \mathrm{UIC}$ \\
\hline 16 & $-25.4(74.3)$ & 0.76 & 0.017 & 0.938 & $-89.08+1.92^{*} \mathrm{UIC}$ \\
\hline 17 & $-36.4(62.0)$ & 0.76 & 0.952 & $<0.001$ & $-0.91+1.51^{*} \mathrm{UIC}$ \\
\hline 18 & $-18.4(101.9)$ & 0.68 & $<0.001$ & $<0.001$ & $68.21+0.63^{*} \mathrm{UIC}$ \\
\hline 19 & $4.4(83.7)$ & 0.62 & 0.042 & 0.009 & $20.94+0.80 * \mathrm{UIC}$ \\
\hline 20 & $-36.6(131.8)$ & 0.57 & $<0.001$ & $<0.001$ & $80.08+0.59 * \mathrm{UIC}$ \\
\hline 21 & $-16.5(139.7)$ & 0.50 & $<0.001$ & $<0.001$ & $49.23+0.53^{*} \mathrm{UIC}$ \\
\hline
\end{tabular}

Mean and standard deviations (SD) derived from Bland \& Altman plots; correlations and conversion formulas from linear regression models; $p_{\text {int }}$ and $p_{\text {slope }}$ are the $p$ values derived from the regression model for the intercept $=0$ and the slope $=1$. $p<0.05$ indicates significant difference. 
Table 2. Standardized median urinary iodine concentrations (UIC) in European monitoring studies

\begin{tabular}{|c|c|c|c|c|}
\hline Country & Year & $\begin{array}{l}\text { Number of } \\
\text { individuals }\end{array}$ & $\begin{array}{c}\text { Standardized } \\
\text { median UIC in } \mu \mathrm{g} / \mathrm{L} \\
(95 \%-\mathrm{Cl})\end{array}$ & $\begin{array}{c}\text { Standardized inter- } \\
\text { quartile-range of } \\
\text { UIC in } \mu \mathrm{g} / \mathrm{L}\end{array}$ \\
\hline
\end{tabular}

\begin{tabular}{|c|c|c|c|c|}
\hline \multicolumn{5}{|c|}{ Studies in school children } \\
\hline Croatia & 2016 & 200 & $222(209 ; 235)$ & $179-282$ \\
\hline Czech Republic & 2006 & 302 & $210(194 ; 225)$ & $103-294$ \\
\hline Germany & 2006 & 14641 & $113(111 ; 115)$ & $61-169$ \\
\hline Hungary & 2018 & 110 & $254(231 ; 276)$ & $163-337$ \\
\hline $\begin{array}{l}\text { Northern Ireland and } \\
\text { Republic of Ireland }\end{array}$ & 2015 & 901 & $110(104 ; 116)$ & $71-162$ \\
\hline Italy & 2016 & 100 & $134(126 ; 143)$ & $114-162$ \\
\hline Latvia & 2011 & 915 & $102(93 ; 111)$ & $34-194$ \\
\hline North Macedonia & 2016 & 1167 & $216(208 ; 224)$ & $149-291$ \\
\hline Montenegro & 2016 & 406 & $181(168 ; 193)$ & $124-248$ \\
\hline Norway & 2015 & 457 & $98(93 ; 103)$ & $69-135$ \\
\hline Poland & 2017 & 1000 & $121(116 ; 126)$ & $82-168$ \\
\hline Portugal & 2011 & 4390 & 107 (106; 108) & $94-156$ \\
\hline Serbia & 2018 & 74 & $187(170 ; 204)$ & $132-239$ \\
\hline Spain & 2011 & 1750 & $179(174 ; 184)$ & $121-246$ \\
\hline Sweden & 2007 & 866 & 127 (122; 132) & $95-166$ \\
\hline
\end{tabular}




\begin{tabular}{|c|c|c|c|c|}
\hline Country & Year & $\begin{array}{l}\text { Number of } \\
\text { individuals }\end{array}$ & $\begin{array}{c}\text { Standardized } \\
\text { median UIC in } \mu \mathrm{g} / \mathrm{L} \\
(95 \%-\mathrm{Cl})\end{array}$ & $\begin{array}{l}\text { Standardized inter- } \\
\text { quartile-range of } \\
\text { UIC in } \mu \mathrm{g} / \mathrm{L}\end{array}$ \\
\hline Switzerland & 2016 & 727 & $152(146 ; 158)$ & $115-201$ \\
\hline \multicolumn{5}{|c|}{ Studies in adults } \\
\hline Croatia & 2016 & 227 & $178(163 ; 193)$ & $111-222$ \\
\hline Cyprus & 2014 & 121 & $99(87 ; 111)$ & $71-150$ \\
\hline Czech Republic & 2006 & 288 & $105(101 ; 108)$ & $83-191$ \\
\hline Finland & 2017 & 1542 & $96(93 ; 100)$ & $62-146$ \\
\hline \multirow{4}{*}{ Germany } & 2012 & 4287 & $65(63 ; 66)$ & $36-103$ \\
\hline & 2011 & 7022 & $51(49 ; 52)$ & $26-82$ \\
\hline & 2008 & 2999 & $93(90 ; 96)$ & $58-136$ \\
\hline & 2001 & 4260 & $72(70 ; 73)$ & $41-107$ \\
\hline Slovenia & 2017 & 292 & $73(63 ; 83)$ & $38-151$ \\
\hline Spain & 2010 & 4383 & $121(118 ; 124)$ & $79-179$ \\
\hline Sweden & 2001 & 565 & $132(123 ; 140)$ & $71-204$ \\
\hline Switzerland & 2016 & 345 & $103(87 ; 120)$ & $63-184$ \\
\hline Turkey & 2017 & 165 & $116(110 ; 121)$ & $89-145$ \\
\hline \multicolumn{5}{|c|}{ Studies in pregnant women } \\
\hline Croatia & 2016 & 202 & $157(147 ; 167)$ & $114-196$ \\
\hline Greece & 2015 & 1135 & $118(114 ; 123)$ & $79-180$ \\
\hline
\end{tabular}




\begin{tabular}{|c|c|c|c|c|}
\hline Country & Year & $\begin{array}{l}\text { Number of } \\
\text { individuals }\end{array}$ & $\begin{array}{c}\text { Standardized } \\
\text { median UIC in } \mu \mathrm{g} / \mathrm{L} \\
(95 \%-\mathrm{Cl})\end{array}$ & $\begin{array}{c}\text { Standardized inter- } \\
\text { quartile-range of } \\
\text { UIC in } \mu \mathrm{g} / \mathrm{L}\end{array}$ \\
\hline Hungary & 2016 & 190 & $144(126 ; 161)$ & $89-276$ \\
\hline Latvia & 2013 & 743 & $39(35 ; 44)$ & $16-75$ \\
\hline North Macedonia & 2017 & 593 & $177(161 ; 192)$ & $90-265$ \\
\hline Poland & 2017 & 300 & $113(101 ; 126)$ & $64-188$ \\
\hline Portugal & 2011 & 4107 & $104(103 ; 105)$ & $65-155$ \\
\hline Romania & 2016 & 317 & $159(142 ; 177)$ & $99-243$ \\
\hline Sweden & 2007 & 459 & $114(105 ; 123)$ & $73-162$ \\
\hline Switzerland & 2016 & 358 & $156(135 ; 177)$ & $81-325$ \\
\hline Northern Ireland (UK) & 2015 & 240 & $66(54 ; 79)$ & $32-113$ \\
\hline
\end{tabular}

$\overline{\mathrm{Cl}}=$ confidence interval calculated by bootstrapping with 500 repetitions 
Figure 1. Standardized European map of median urinary iodine concentrations (UIC); studies have been selected for each country in the following order of priority: most recent study in (i) schoolchildren, (ii) adults, (iii) pregnant women; grey shadings indicate "no data available"

Figure 2. Standardized European map of median urinary iodine concentrations (UIC) in school children; grey shadings indicate "no data available"

Figure 3. Standardized European map of median urinary iodine concentrations (UIC) in adults; grey shadings indicate "no data available"

Figure 4. Standardized European map of median urinary iodine concentrations (UIC) in pregnant women; grey shadings indicate "no data available" 


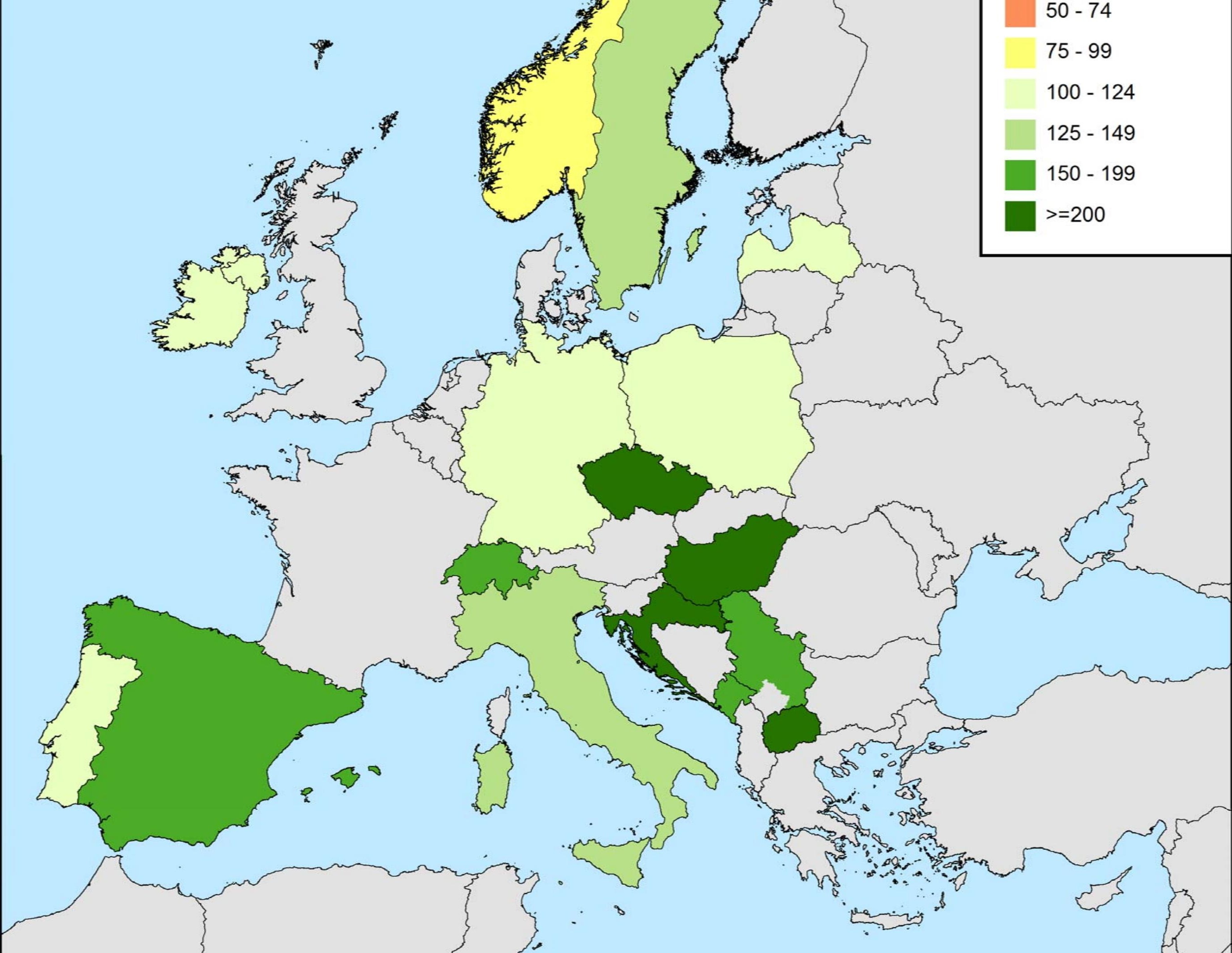




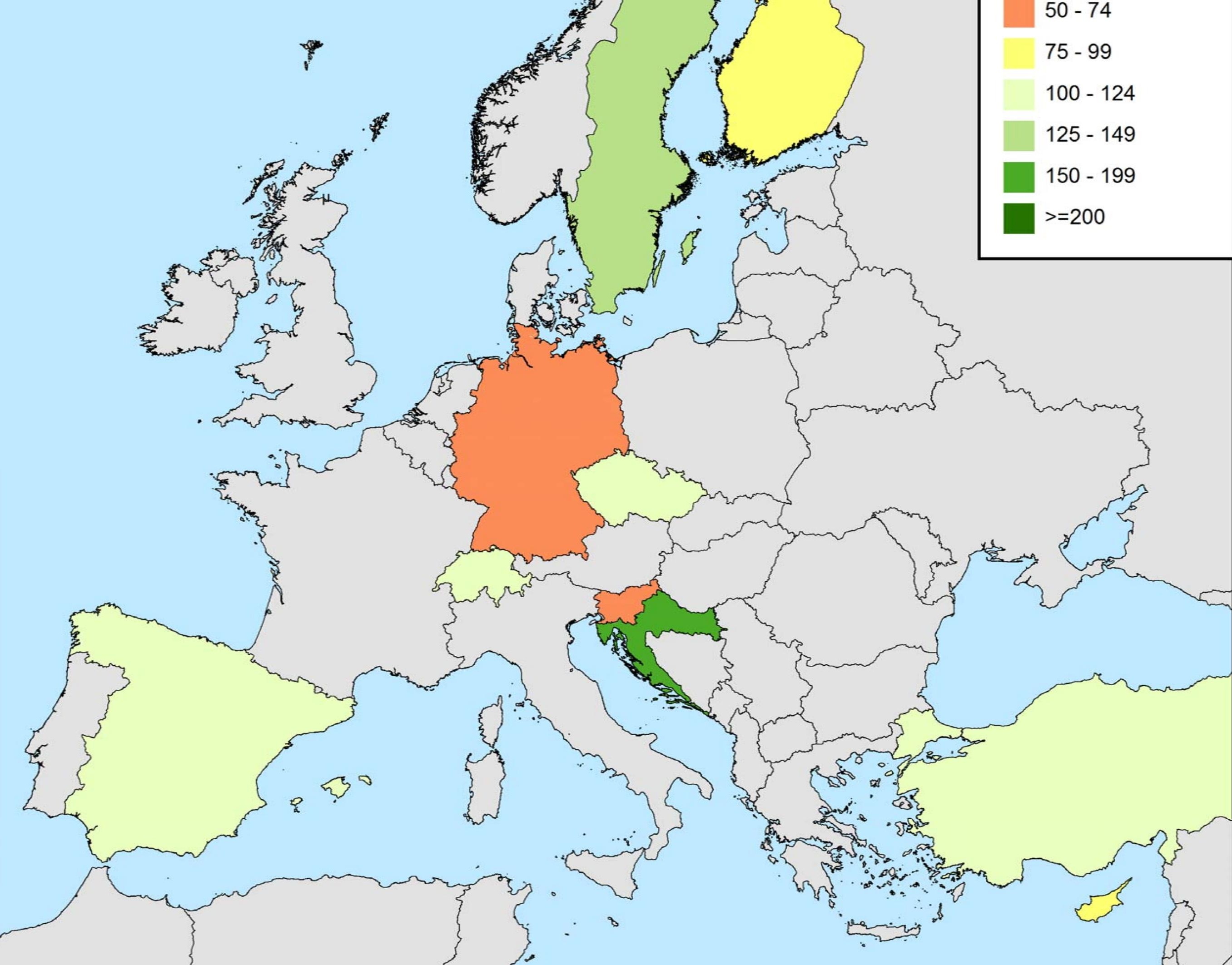




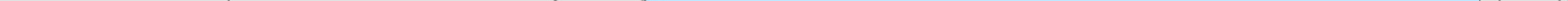

